\title{
A comparative study of muscle texture and intensity of Kudoa thyrsites infection in farm-reared Atlantic salmon Salmo salar on the Pacific coast of Canada
}

\author{
Sophie St-Hilaire ${ }^{1,2, *}$, Michelle Hill ${ }^{1}$, Michael L. Kent ${ }^{2}$, David J. Whitaker ${ }^{2}$, Carl Ribble ${ }^{1}$ \\ ${ }^{1}$ Department of Herd Medicine, Western College of Veterinary Medicine, University of Saskatchewan, 52 Campus Drive, \\ Saskatoon, Saskatchewan, Canada S7N 5B4 \\ ${ }^{2}$ Department of Fisheries and Oceans, Pacific Biological Station, Nanaimo, British Columbia, Canada V9R 5K6
}

\begin{abstract}
The muscle texture of 32 Atlantic salmon Salmo salar infected with the myxosporean Kudoa thyrsites was compared to the texture of 32 uninfected Atlantic salmon to determine the relationship of $K$. thyrsites with post mortem muscle deterioration or soft flesh. Flesh texture was evaluated objectively with an Instron texture assessment machine that measured the force required to pass a Kramer 10 blade apparatus through $40 \mathrm{~g}$ of muscle tissue. A significant negative correlation $(R=-0.45, p=0.004)$ was found between the firmness of flesh texture $6 \mathrm{~d}$ after harvest and the number of $K$. thyrsites spores in the muscle tissue. In addition, there was a threshold intensity of $K$. thyrsites spores necessary before any gross signs of muscle deterioration. The correlation found in this study is highly suggestive that this parasite is a cause either directly or indirectly of muscle deterioration in Atlantic salmon.
\end{abstract}

KEY WORDS: Kudoa thyrsites $\cdot$ Atlantic salmon $\cdot$ Muscle texture $\cdot$ Threshold

\section{INTRODUCTION}

Flesh quality is a concern with any industry that sells a fresh meat product. Poor muscle quality of fish after harvest has been attributed to many factors. These factors include processing problems such as handling fish while in rigor mortis, prolonged storage time, inadequate storage conditions, and poor 'stun and bleed' techniques (Talbot 1994). Other associated factors include high fat feeds, stress, and quality of the fish at harvest (Talbot 1994). Harrell \& Scott (1985), Whitaker \& Kent (1991), and Barja \& Toranzo (1993) isolated Kudoa thyrsites from Atlantic salmon with poor flesh quality. This myxosporean parasite has been associated with post harvest autolysis in other species of marine fishes (Patashnik \& Groninger 1964, Langdon

•E-mail: hilaires@pbs.dfo.ca et al. 1992). Several research groups have found the intensity of infection with Kudoa sp. in Pacific hake Merluccius productus to be correlated to muscle autolysis (Tsuyuki et al. 1982, Kudo et al. 1987). These findings suggest that, although little is known about the specific effects of $K$. thyrsites in Atlantic salmon, the parasite may be an important cause of poor flesh quality for this species of fish. The purpose of this study, therefore, was to investigate if there is a correlation between poor flesh texture and intensity of $K$. thyrsites infections in seapen reared Atlantic salmon on the Pacific coast of Canada.

\section{MATERIAL AND METHODS}

The 64 fish used in this experiment were supplied by several Atlantic salmon farming companies in British Columbia, Canada, over a period of several months. 
They were either sexually 'reconditioning' (i.e. fish that had undergone sexual maturation and were reabsorbing their gonadal tissue) or utility grade fish. The latter group were downgraded at the processing plants for different reasons. These included skeletal deformities, emaciation, excessive scale loss, scarring, processing cuts, or a combination of these. Reconditioned and downgraded fish were used because they were relatively inexpensive, and according to the industry, they were more likely to be infected with Kudoa thyrsites. All fish used were market-size ( 3 to $4 \mathrm{~kg}$ ) except 1 group of 4 fish that were between 1 to $2 \mathrm{~kg}$. This latter group of fish were supplied by the Pacific Biological Station, Department of Fisheries and Oceans, in $\mathrm{Na}$ naimo, B.C., Canada.

There was some variation in the general appearance of fish used in this study at the time of harvest. To decrease this variability we divided the fish into 2 groups based on a subjective examination of the fish when we received them. Twenty-six fish from 4 harvests evaluated were considered to be poor quality at the time of processing. This group of fish was designated as group B. In addition, 16 of these fish were not eviscerated until $1 \frac{1}{2} \mathrm{~d}$ after harvest, which may have contributed to muscle autolysis. The other 38 fish from 6 harvests, designated group A, were eviscerated at the processing plant and were in better condition at time of processing. Once fish were collected, they were kept on ice in styrofoam coolers that were placed in a refrigerator $\left(4^{\circ} \mathrm{C}\right)$ for $6 \mathrm{~d}$. This time period was selected because it is typical of the time it takes for fish to reach the retail markets.

Fish were filleted after $6 \mathrm{~d}$. The fillets were rinsed with water to remove scales and $40 \mathrm{~g}$ of muscle tissue was collected from the cranio-dorsal, medial lateral, and caudal regions of the right side of each fillet. Any bones, skin, and scales were removed from samples prior to texture analysis. Muscle texture was first assessed subjectively by observing the recoil of the muscle after digital pressure and the general appearance of the flesh. These observations were recorded as normal or abnormal (i.e. soft). Muscle texture was then assessed objectively using an Instron model 1122 texture assessment instrument (Canton, MA, USA) with a Kramer 10-blade shear compression cell. This machine recorded the force (measured in pounds, lbs) required to push the blades through $40 \mathrm{~g}$ of muscle tissue evenly distributed in the cell chamber. Following texture analysis, each sample was retrieved and saved for evaluation of the intensity of Kudoa thyrsites infection. The blades and cell chamber of the Instron machine were thoroughly cleaned with soap and water between each sample to avoid spore contamination.

A sub-sample of $24 \mathrm{~g}$ of muscle was taken from each original $40 \mathrm{~g}$ sample of tissue. This sub-sample was mixed with $10 \mathrm{ml}$ of physiological saline in a sterile plastic bag and placed in a Stomacher Lab Blender 80 (Seaward Laboratory, London, UK) for 3 to $5 \mathrm{~min}$. Five grams of this slurry were then transferred to a $150 \mathrm{ml}$ Erlenmeyer flask to which $100 \mathrm{ml}$ of $0.5 \%$ trypsin solution ( $\mathrm{pH}=7.2)$ was added. The trypsin mixture was shaken vigorously, then placed in a shaker bath kept at $37^{\circ} \mathrm{C}$, and gently agitated for $30 \mathrm{~min}$. At this time, the samples were manually shaken, replaced in the bath, and agitated for an additional $30 \mathrm{~min}$.

To concentrate the samples, the trypsin mixture was divided into two $50 \mathrm{ml}$ centrifuge tubes and centrifuged at $3000 \times \mathrm{g}$ for $15 \mathrm{~min}$ at $10^{\circ} \mathrm{C}$. The supernate was decanted following centrifugation, and $3 \mathrm{ml}$ of water was added to each concentrated pellet and mixed with a VWR Vortex Mixer (Scientific Industries Ltd, Bohemia, NY, USA). Wet mounts were prepared by pipetting $20 \mu \mathrm{l}$ of this suspension onto glass slides. Because each $5 \mathrm{~g}$ sample of tissue was distributed between 2 centrifuge tubes, 2 slides were prepared for each sample, 1 from each tube. These were screened for Kudoa thyrsites spores using a Leitz Dialux 20 compound microscope at $192 \times$ and phase contrast illumination. Slides were examined in an 'S' shaped pattern. If no spores were found, the samples were considered to be negative for $K$. thyrsites. If spores were identified, then 5 fields on each slide were selected, 1 in each corner and 1 in the centre of the slide, and the number of spores present in these fields was determined.

The number of Kudoa thyrsites spores per gram of tissue was calculated by determining the amount of tissue in the area of the slide examined and dividing the number of spores counted in that area by this number. One ocular field at $192 \times$ had an area of $0.916 \mathrm{~mm}^{2}$. In slides that had many spores, 10 fields were examined in total; therefore the total area observed was $9.16 \mathrm{~mm}^{2}$. There was $0.320 \mathrm{mg}$ of tissue in this area. This value assumes that the tissue was evenly distributed throughout the slide. In order to calculate the number of spores per gram of tissue when a slide contained very few spores and thus more than 10 fields were evaluated, the area of the slide examined was estimated based on the number of ocular fields examined.

The data in this study did not meet the assumptions of a parametric test. The variance of the residuals for both groups of fish was not homogeneous and assumption of normality was not met. Therefore, Spearman rank coefficients were used to determine whether there was a significant correlation between texture and spore counts in group A and group B fish (Norman \& Streiner 1994, p. 176-177). A Rank sum test was used to determine whether the texture values of lightly infected fish (spore count greater than zero but less than 20000 spores $\mathrm{g}^{-1}$ of muscle) were significantly different from the values obtained from uninfected fish 
in both groups separately (Norman \& Streiner 1994, p. 171). The texture readings for uninfected fish in groups $A$ and $B$ were normally distributed so 1-way ANOVA was used to determine whether there was a significant difference between the 2 groups of uninfected fish (Norman \& Streiner 1994, p. 64-72).

Descriptive statistics and all statistical tests were calculated using a microcomputer statistics software package (Statistix version 4.1, Analytical Software, Tallahassee, FL, USA, 1994).

\section{RESULTS}

The muscle texture and the intensity of Kudod thyrsites infections in 64 fish were determined for this study: 38 fish in group A and 26 fish in group B. The relationship between the muscle texture of a fish and the number of spores found per gram of that muscle tissue is shown in Fig. 1A, B for fish in groups A and B, respectively.

The Spearman's Rho coefficients for fish in groups A and $B$ were $-0.45(p=0.004)$ and $-0.59(p=0.001)$ respectively. This indicated that there was a significant negative correlation between the number of spores per gram of tissue and the firmness of the infected muscle in both groups of fish.

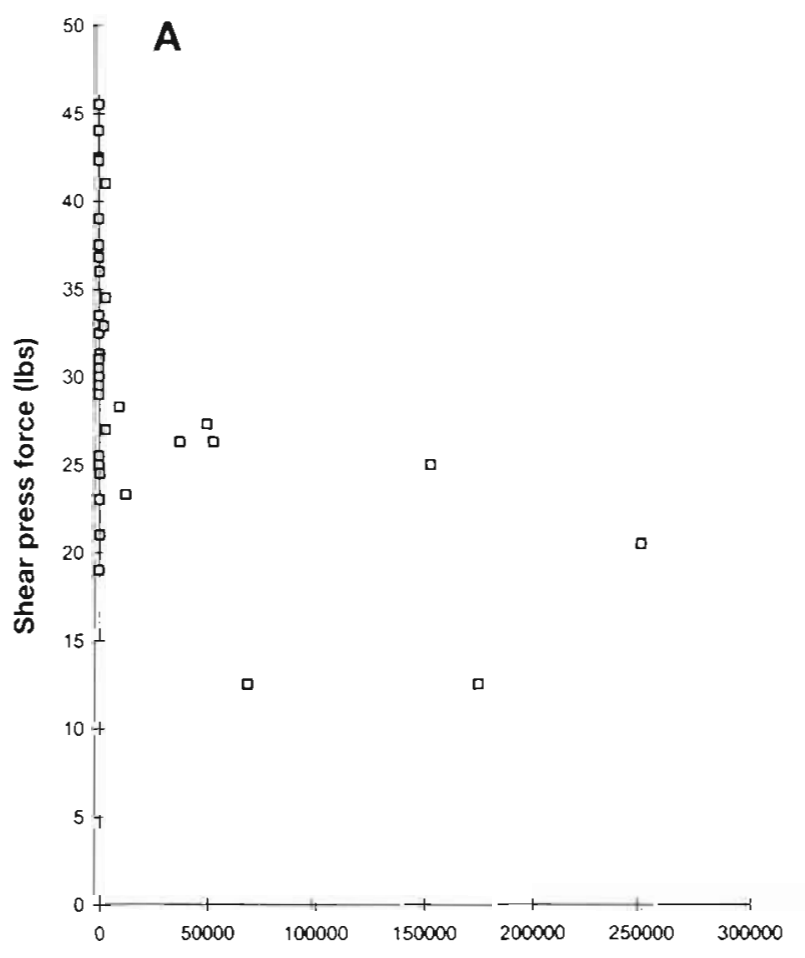

Muscle samples from group A and group B fish with spore counts greater than 0 but less than 20000 spores $\mathrm{g}^{-1}$ of tissue were not significantly softer than samples that did not contain Kudoa thyrsites spores (group A, $p=0.28$; group $B, p=0.24$ ). Furthermore, the correlation between texture and spore count was stronger when these lightly infected fish were removed from the study. The Spearman's Rho coefficients for fish in groups A and B when fish with spore counts greater than 0 but less than 20000 were excluded from the analysis were $-0.62(p<0.001)$ and $-0.89(p<0.001)$ respectively.

Although there was a wide range of texture values for uninfected muscle in both group $A$ and group $B$, the muscle texture value of uninfected fish from group $A$ was significantly higher than the texture value of uninfected fish from group B ( $p=0.0015)$.

When we categorized the muscle texture readings from this study into acceptable and unacceptable based on the criterion that most flesh with a texture reading of 25 lbs or less was noticeably soft on subjective evaluation, we found that $68 \%$ of the uninfected fish were of acceptable quality and $38 \%$ of the infected fish were of acceptable quality. If we further break this down and look at the fish in group A and B separately, we see that most of the uninfected unacceptable fish were in group $B(62 \%)$ and that most of the fish that

B

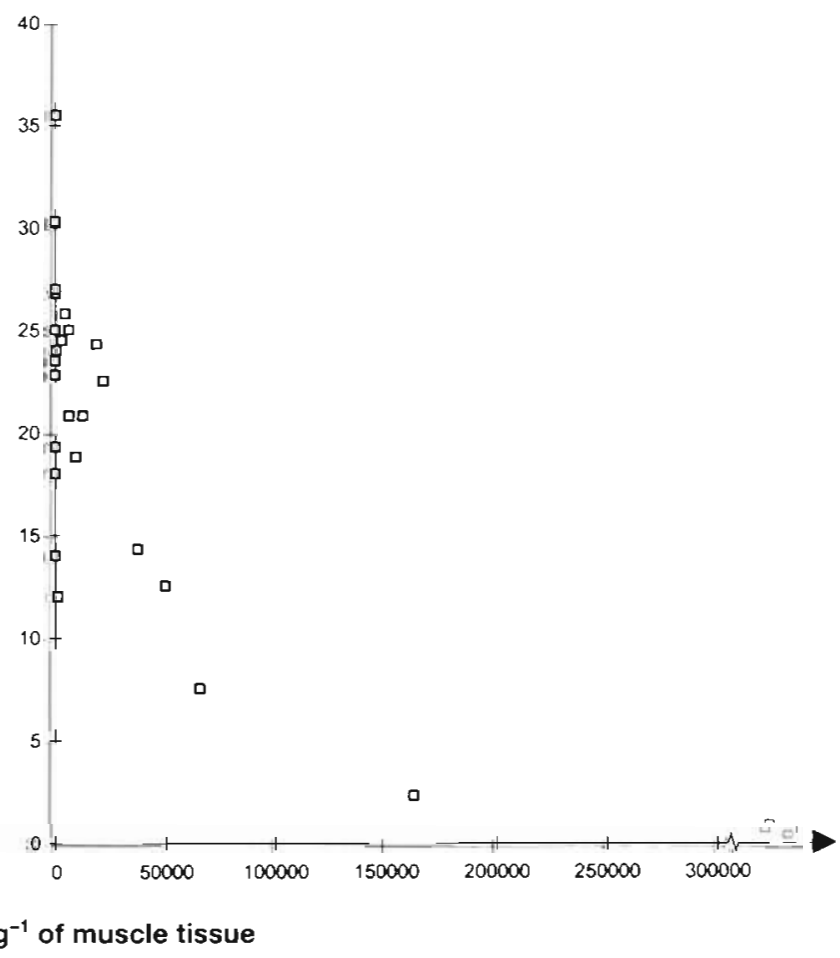

Fig. 1. Salmo salar. Number of Kudoa thyrsites spores versus muscle texture (measured by shear press force required to penetrate $40 \mathrm{~g}$ of muscle tissue) $6 \mathrm{~d}$ post harvest for fish in groups $\mathrm{A}$ and $\mathrm{B}$ 
Table 1 Salmo salar. Acceptable and unacceptable muscle texture $6 \mathrm{~d}$ post harvest versus the presence or absence of Kudoa thyrsites spores in the muscle tissue for lish in groups A and B

\begin{tabular}{|c|c|c|c|}
\hline & $\begin{array}{l}\text { Unacceptable } \\
\text { texture } \\
(\leq 25 \text { lbs })^{d}\end{array}$ & $\begin{array}{l}\text { Acceptable } \\
\text { texture } \\
(>25 \text { lbs })^{\text {a }}\end{array}$ & Total \\
\hline \multicolumn{4}{|l|}{ Group A } \\
\hline K. thyrsites spores presen & 8 & 11 & 19 \\
\hline$K$. thyrsites spores absent & 3 & 16 & 19 \\
\hline Total & 11 & 27 & 38 \\
\hline \multicolumn{4}{|l|}{ Group B } \\
\hline K. thyrsites spores presen & 16 & 4 & 20 \\
\hline$K$ thyrsites spores absent & 5 & 1 & 6 \\
\hline Total & 21 & 5 & 26 \\
\hline \multicolumn{4}{|c|}{$\begin{array}{l}\text { "Force required to push through } 40 \mathrm{~g} \text { of muscle tissue } \\
\text { evenly distributed in the } 10 \text {-blade cell chamber of the } \\
\text { Instron texture assessment machine }\end{array}$} \\
\hline
\end{tabular}

were infected and acceptable were in group A (73\%) (Table 1). Over half $(58 \%)$ of the infected fish in group A did not show noticeable signs of muscle deterioration $6 \mathrm{~d}$ after harvest.

\section{DISCUSSION}

A correlation was found between the intensity of Kudoa thyrsites infections and flesh quality in Atlantic salmon. High intensity infections with this myxosporean parasite resulted in severe autolysis of the somatic musculature of fish $6 \mathrm{~d}$ post mortem. This finding supports previous reports in the literature that $K$. thyrsites is associated with post mortem muscle deterioration in Atlantic salmon (Harrell \& Scott 1985 , Whitaker \& Kent 1991, Barja \& Toranzo 1993). It also supports anecdotal reports from producers in the Atlantic salmon industry and suggests that preventing the shipment of fish infected with $K$. thyrsites would decrease the number of poor flesh quality claims received by the industry.

Interestingly, many fish with less than 20000 spores $\mathrm{g}^{-1}$ of muscle tissue appeared to have the same muscle texture as uninfected fish. When these lightly infected fish were removed from the analysis, a stronger corre. lation was found between the intensity of Kudoa thyrsites infections and the texture of the infected muscle tissue. A threshold level of $K$. thyrsites infection may therefore be necessary in Atlantic salmon to produce noticeable post mortem muscle deterioration. A similar threshold effect has been reported in Pacific hake Merluccius productus infected with Kudoa paniformis (Kudo et al. 1987).

Another factor besides Kudoa thyrsites that appeared to affect the post mortem flesh texture of the unin- fected fish was the general condition of the fish at time of harvest. Some of the fish were in noticeably poorer condition upon arrival in our laboratory than others. To decrease the effect of this factor on the results of the study we divided the fish into 2 groups, group A and B. Using subjective and objective texture evaluation methods, it was found that the average texture reading $6 \mathrm{~d}$ after harvest for uninfected fish in group $B$ was significantly lower than uninfected fish in group $A$. In fact, several of the uninfected fish in group $B$ were softer than infected fish in group A. When data from this study were categorized into acceptable and unacceptable flesh quality 6 d after harvest, only 1 out of the 6 uninfected fish in group $B$ had flesh quality that was considered acceptable (Table 1). In group A, 16 of the 19 uninfected fish had acceptable flesh quality. This finding suggested that the general condition of fish at time of harvest aiffected the post mortem fiesh texture of fish 6 d later. Because all fish included in this study were utility grade or reconditioned fish from the processing plants, it is not surprising that such a high percentage of uninfected fish (32\%) were of unacceptable quality; however, it makes the comparison of Kudoa infected and uninfected fish more difficult. By taking an objective measurement of the initial quality of the fish muscle in future studies, it will be possible to better control the effect of this confounder on post harvest flesh texture. Removing the variation in the quality of flesh at time of harvest may remove the threshold effect observed in this study.

The intensity of Kudoa thyrsites infections was determined by quantifying the number of spores per gram of muscle tissue, the best method available for this species of fish. Unfortunately, presporogenic or unsporulated stages of the parasite are not detectable using this technique and parasites that were just beginning to undergo sporogenesis were likely underrepresented. With a more sensitive method of detecting all stages of $K$. thyrsites infections it is possible that some of these unacceptable negative fish would have been found infected with $K$. thyrsites.

Overall, the findings of this study indicated that the presence of the sporulated stage of Kudoa thyrsites was associated with post mortem muscle autolysis in Atlantic salmon. In addition, a certain intensity of infection appeared to be necessary before fish showed signs of muscle deterioration. It is possible that other factors, such as storage time and temperature, affect the threshold intensity of $K$. thyrsites infection necessary for noticeable muscle deterioration. If such factors exist, their manipulation may be useful in the management of $K$. thyrsites associated 'soft flesh'. It may also be possible for salmon growers to reduce the number of Kudoa-related 'soft flesh' by decreasing the number of fish that undergo sexual maturation, since these fish 
have been found to have a higher prevalence of $K$. thyrsites (St-Hilaire 1996). The fact that we found a higher incidence of $K$. thyrsites infection and severity of infection in the fish in group B suggests that utility grade fish may be at higher risk for infection as well.

It is important for the Atlantic salmon industry to develop a management strategy for reducing the number of Kudoa infected fish because it is clear that a certain number of infected fish will develop Kudoa related post harvest muscle autolysis.

Acknowledgements. The fish used in this study were donated by various Atlantic salmon producers in British Columbia. Support in kind was provided by the Pacific Biological Station in Nanaimo, B.C.

\section{LITERATURE CITED}

Barja JL, Toranzo AE (1993) Myoliquefaction post-mortem caused by the myxosporean Kudoa thyrsites in reared Atlantic salmon in Spain. Bull Eur Assoc Fish Pathol 13(3): $86-88$

Harrell LW, Scott TM (1985) Kudod thyrsites (Gilchrist) (Myxosporea: Multivavulida) in Atlantic salmon, Salmo salar. J Fish Dis 8:329-332

Editorial responsibility: Wolfgang Körting, Hannover, Germany
Kudo G, Barnett $\mathrm{HJ}$, Nelson W (1987) Factors affecting cooked texture quality of Pacific whiting, Merluccius productus, fillets with particular emphasis on the effects of infection by the myxosporeans Kudoa paniformis and $K$. thyrsites. Fish Bull 85(4):745-756

Langdon JS, Thorne T, Fletcher WJ (1992) Reservoir hosts and new clupeoid host records for the myoliquefactive myxosporean parastie Kudoa thyrsites (Gilchrist). J Fish Dis 15:459-471

Norman GR, Streiner DL (1994) Biostatistics. The bare essentials. Mosby, St. Louis, MI, p 64-72, 171

Patashnik M, Groninger HS (1964) Observations on the milky condition in some Pacific coast fishes. J Fish Res Bd Can 21(2):335-346

St-Hilaire S (1996) The epidemiology of Kudoa thyrsites in Atlantic salmon pen-reared in British Columbia, Canada. MSc thesis, University of Saskatchewan, Saskatoon

Talbot C (1994) Soft flesh. Food for thought 2(3):16

Tsuyuki H, Williscroft SN, Kabata Z, Whitaker D (1982) The relationship between acid and neutral protease activities and the incidence of soft cooked texture in the muscle tissue of Pacific hake (Merluccius productus) infected with Kudoa paniformis and/or $K$. thyrsites, held for varying times under different pre-freezing chilled storage conditions. Can Tech Rep Fish Aquat Sci 1130

Whitaker DJ, Kent ML (1991) Myxosporean Kudoa thyrsites: a cause of soft flesh in farm-reared Atlantic salmon. J Aquat Anim Health 3:291-294

Submitted: December 9, 1996; Accepted: September 25, 1997 proofs received from author(s): November 14, 1997 